\title{
COST - BENEFIT ASSESSMENT OF AIRCRAFT SAFETY
}

\author{
Ivana Čavka ${ }^{1}$, Olja Čokorilo ${ }^{2}$ \\ ${ }^{1}$ Scientific Research Center Ltd., Obilićev venac 4/3, 11000 Belgrade, Serbia \\ ${ }^{2}$ University of Belgrade, Faculty of Transport and Traffic Engineering, Vojvode Stepe 305, 11000 \\ Belgrade, Serbia
}

Received 20 July 2012; accepted 5 September 2012

\begin{abstract}
The constant increase of air traffic volume causes the requirements for development and implementation of numerous measures that will enable monitoring of the safety level in the aviation organizations. An inseparable element of the process of implementing an adequate safety management system in aviation refers to the analysis of economic parameters for assessing the risk of aircraft accidents. Based on the statistical data related to the accidents of aircraft A320, which is considered in this paper, the main indicators of safety were analyzed. However, since aircraft accidents are among a group of rare events, historical data may not always be used to determine the level of safety. In such cases, it is necessary to develop mathematical models that will calculate the safety level. Therefore, this paper presents a methodology for assessing the costs of safety in the event of an aircraft accident, and which is a useful tool in the safety management system that could indicate the potential financial loss in case of an aircraft accident, but also the benefits that may arise by making investments in improving the safety level.
\end{abstract}

Keywords: aircraft, safety, cost-benefit, safety management system.

\section{Introduction}

Contemporary transport analyses are based on safety and economical equilibrium. Air transport sector recognizes $2 \mathrm{P}$ dilemma as the crucial decision making tool. It means that all interested parties in aviation are balancing between productivity and profitability limits. According to its complexity, aviation becomes the leader in systematic approach of safety "thinking" which is based on successful development and implementation of strategic safety management system (SMS). SMS could be understood as management of hazards and safety risks in aviation, which are always present in all aircraft operations (ICAO Doc 9859, 2009). Those safety risks could be measured, mitigated and strongly limited but some risks are always present in such complex systems. Many studies explain the problem of managing safety risks in aviation (Čokorilo, 2008; Čokorilo et al., 2011). Safety investment is guarantee for successful longterm profitability, but required safety level achievement relates on potential cost of the system damage or aircraft accident. It means that decision makers should be involved into cost-benefit analysis of potential aircraft crash.

\footnotetext{
${ }^{1}$ Corresponding author: i.cavka@ijtte.com
} 


\section{Aircraft A320 Safety Analysis}

The forthcoming analysis is based on the aircraft Airbus A320 that is the most operated regional aircraft on the European airports. Aircraft A320 have had 46 recorded accidents from 1988 until 2012. Total number of fatalities is 655 , including passengers, crew members and the third parties, and which is $13 \%$ of total persons who could be injured as a result of an A320 accident in the considered period. Fig. 1 presents total number of fatalities by the year of accident.

Number of casualties is directly related to the aircraft accident severity. Therefore, it is important to investigate A320 accident history (Fig. 2).

Contemporary safety studies show that the most critical flight phases are takeoff and landing. During those phases pilot has to accommodate aircraft speed and height as well as many other parameters that indicate aircraft performance. Statistical data for A320 confirm this fact from early production days until now. Fig. 3 shows A320 number of accidents by flight phase. It also shows that certain number of accidents happened during the aircraft operations on the ground, caused by fire in the hangar, fuel tanking on the apron, etc.

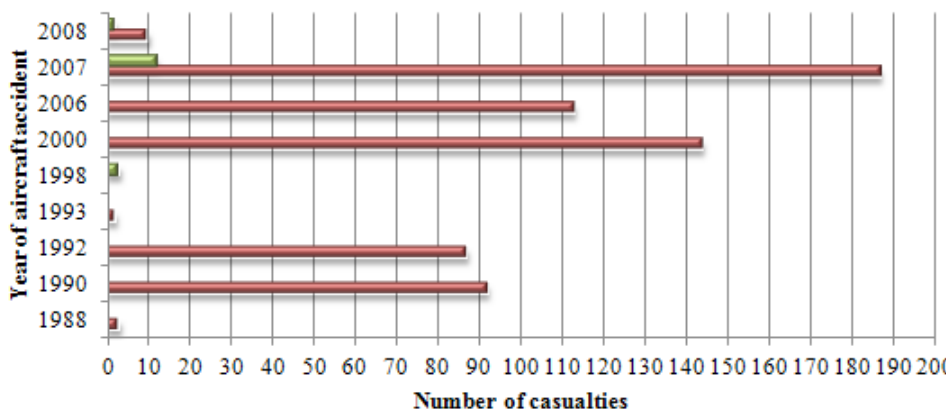

Ground casualties

On board casualties

Fig. 1.

Annual Number of Casualties Related to A320 Accidents (1988-2012)

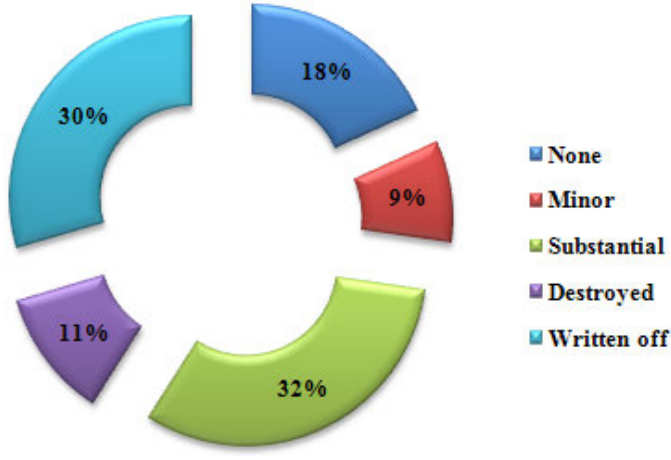

Fig. 2.

Aircraft A320 Accident Severity Type (1988-2012) 
Fig. 3.

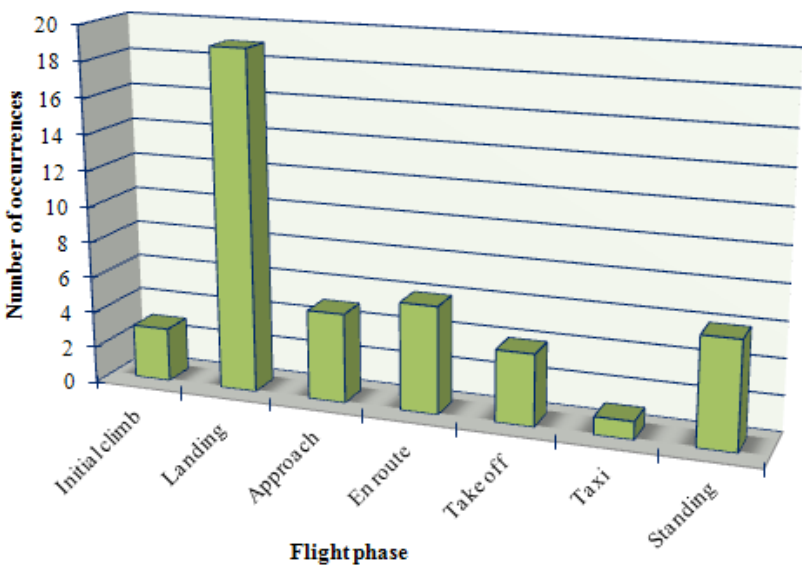

Number of A320 Accidents by Flight Phase (1988-2012)

\section{Cost-Benefit Analysis of Aviation Safety. Case Study: A320-200}

\subsection{Aircraft A320 Accident Costs}

The methodology for accident costs evaluation is based on previous research by Čokorilo et al. (2010a). The presented cost evaluation based on Čokorilo et al. (2010b) has been improved by the year 2012. Table 1 presents aircraft safety costs and their main characteristics (adjusted from 2012 prices). According to the cost implication, two categories were found: direct and indirect safety costs (NLR, 2001). The first one is easy to evaluate when an aircraft accident occurs and could be recognized as insurance related costs. Indirect costs are hard to be recognized and they are deeply related to the aircraft accident.

Determining the costs of aircraft accidents primarily depends on the aircraft type and level of damage. Cost-Benefit analysis presented in this paper will be conducted on the aircraft A320-200, equipped with 150 passenger seats.
Estimation of the total safety costs for a given aircraft is performed based on the input data and assumptions listed below.

\subsubsection{Aircraft Direct Safety Costs}

Aircraft accident costs classified as direct safety costs (DSC) are:

Aircraft physical damage. In order to determine the value of the costs that are related to aircraft damage, it is necessary to estimate the aircraft market value. Aircraft market value depends on the average price of a new aircraft of a given type, and the average age of that aircraft. Table 2 shows the average price of new Airbus aircraft in 2012.

Airbus has increased the average price of its aircraft by $3.9 \%$ (calculated according to Airbus' standard escalation formula over the January 2011 to January 2012 period), except for prices of A320neo family, which average price has increased by up to $6.1 \%$. The new prices reflect a strong demand for modern, eco-efficient aircraft. 
Table 1

Aircraft Safety Costs

\begin{tabular}{|c|c|}
\hline Cost Category & Cost Description \\
\hline \multirow{5}{*}{ Aircraft physical damage } & Minor (15\% damage) \\
\hline & Moderate (50\% damage) \\
\hline & Major ( $80 \%$ damage) \\
\hline & Disaster (100\% damage) \\
\hline & Catastrophic (100\% damage) \\
\hline Possible loss of resale value & $5-10 \%$ of aircraft market value (for partial losses) \\
\hline Aircraft loss of use & Monthly lease cost $\mathrm{x}$ assumed months to replace \\
\hline Aircraft loss of investment return & Part of aircraft loss of use \\
\hline \multirow{3}{*}{ Site contamination and clearance } & Wide body: $1.65-3.88 \mathrm{M} \$$ \\
\hline & Narrow body: $0.97-1.79 \mathrm{M} \$$ \\
\hline & Smaller aircraft: $0.18-0.27 \mathrm{M} \$$ \\
\hline \multirow{2}{*}{ Airline costs for delay } & Wide body: $30.78 \$ \mathrm{x}$ number of passengers on flight \\
\hline & Narrow body: $27.36 \$ \mathrm{x}$ number of passengers on flight \\
\hline Airport closure & $\begin{array}{l}\text { Airport disruption depends on severity of the accident. } \\
\text { Only applicable if accident occurs on or close to the runway. }\end{array}$ \\
\hline Deaths and injuries & $\begin{array}{l}\text { Value of a Statistical Life (VOSL): } 0.9-3.65 \mathrm{M} \$ \\
\text { VOSL differs per country. Value of injury is } 13 \% \text { of VOSL. }\end{array}$ \\
\hline Loss of staff investment & Replacement cost per pilot: 62127.57 \$ \\
\hline \multirow{2}{*}{ Loss of baggage } & Underfloor cargo carried on passenger flights: $151842.05 \$$ \\
\hline & Personal baggage on passenger flights: $62127.57 \$$ \\
\hline Search and Rescue (SAR) costs & Average SAR costs: $0.83 \mathrm{M} \$$ \\
\hline Airline immediate response & Average costs per accident: $0.68-4.10 \mathrm{M} \$$ \\
\hline \multirow{3}{*}{ Cost of accident investigation } & State: $0.14-136.79 \mathrm{M} \$$ \\
\hline & Airline: $1.37 \mathrm{M} \$$ \\
\hline & Manufacturer: $1.37 \mathrm{M} \$$ \\
\hline Third party damage & $\begin{array}{l}\text { Third party death and injury: use similar VOSL as in passenger } \\
\text { death and injury + third party physical damage }\end{array}$ \\
\hline Loss of investment income & These costs are reflected in insurance premiums \\
\hline Increased cost of insurance & Loss of $20 \%$ insurance discount for airline involved \\
\hline \multirow[t]{2}{*}{ Loss of reputation } & $\begin{array}{l}\text { Airline loss of turnover: } 0-524.38 \mathrm{M} \$ \text { (Huge range. Loss to } \\
\text { society is far less than to airline, since major part of reduced } \\
\text { demand will shift to other airline.) }\end{array}$ \\
\hline & $\begin{array}{l}\text { Manufacturer (Likely that airlines will buy aircraft from other } \\
\text { manufacturers.) }\end{array}$ \\
\hline
\end{tabular}

Source: NLR (2001) 
Table 2

Unit Value of New Aircraft (2012)

\begin{tabular}{|c|c|}
\hline Aircraft Type & Unit Cost $[\mathbf{M \$}]$ \\
\hline A318 & 67.7 \\
\hline A319 & 80.7 \\
\hline A320 & 88.3 \\
\hline A321 & 103.6 \\
\hline A319neo & 88.8 \\
\hline A320neo & 96.7 \\
\hline A321neo & 113.3 \\
\hline A330-200 & 208.6 \\
\hline A330-200F & 211.5 \\
\hline A330-300 & 231.1 \\
\hline A350-800 & 245.5 \\
\hline A350-900 & 277.7 \\
\hline A350-1000 & 320.6 \\
\hline A380-800 & 389.9 \\
\hline
\end{tabular}

Source: Airbus (2012)

Table 3

Average Loss of Aircraft Value with Age

\begin{tabular}{|c|c|c|}
\hline $\begin{array}{c}\text { Age } \\
\text { (year) }\end{array}$ & $\begin{array}{c}\text { Value } \\
{[\%]}\end{array}$ & $\begin{array}{c}\text { A320-200 } \\
\text { Average Value }[\mathbf{M}]\end{array}$ \\
\hline 0 & 100 & 88.3 \\
\hline 1 & 92 & 81.24 \\
\hline 2 & 86 & 75.94 \\
\hline 3 & 81 & 71.52 \\
\hline 4 & 76 & 67.11 \\
\hline 5 & 71 & 62.69 \\
\hline 6 & 66 & 58.28 \\
\hline 7 & 62 & 54.75 \\
\hline 8 & 58 & 51.21 \\
\hline 9 & 54 & 47.68 \\
\hline 10 & 52 & 37.19 \\
\hline 11 & 49 & 43.27 \\
\hline 12 & 46 & 40.62 \\
\hline 13 & 44 & 38.85 \\
\hline 14 & 41 & 36.20 \\
\hline 15 & 40 & 35.32 \\
\hline 16 & 39 & 34.44 \\
\hline 17 & 38 & 33.55 \\
\hline 18 & 38 & 33.55 \\
\hline 19 & 37 & 32.67 \\
\hline 20 & 36 & 31.79 \\
\hline & & \\
\hline
\end{tabular}

The average value of a new aircraft can vary depending on the period being observed. Price values of the considered aircraft A320-200 adjusted by its average age are given in Table 3 .

As an input parameter in the calculation of the total safety costs, the average age of the aircraft A320 was chosen by random number generator, by which it was obtained that A320 average age is 12 years. Thus, the average market price of aircraft A320 in a given year was 40.62 M\$.

Cost of aircraft physical damage is determined on the basis of the level of damage caused to the aircraft, by multiplying obtained market value of the aircraft with a corresponding damage ratio (Table 4).

\section{Table 4}

Accident Severity Classification

\begin{tabular}{|c|c|c|}
\hline Level & Damage [\%] & Death [\%] \\
\hline Minor & 15 & 0 \\
\hline Moderate & 50 & 0 \\
\hline Major & 80 & 0 \\
\hline Disaster & 100 & 30 \\
\hline Catastrophic & 100 & 80 \\
\hline
\end{tabular}

Source: NLR (2001)

Possible loss of resale value. These losses amount to $5-10 \%$ of the aircraft market value, which is determined as described above, and they are applied only to cases with partial damage to the aircraft (minor, moderate and major form of accident). For the purposes of the analysis carried out in this paper, accepted value of the possible loss of resale value is $5 \%$.

Aircraft loss of use. Costs that are a consequence of the exclusion of aircraft from flight operations depend on the monthly leasing costs that are expressed as a percentage of the aircraft average market value (Table 5) and the estimated number 
of months for aircraft replacement. Period of time that is required for repair of aircraft or its replacement by a new aircraft in the fleet is usually six months up to one year and refers to the time required to complete the safety investigation, including all procedures and reports. It was assumed that this period is three, six and nine months for the minor, moderate and major form of the accident, respectively.

Table 5

Estimated Monthly Lease Rates Expressed in Current Market Value [\%]

\begin{tabular}{|c|c|c|}
\hline $\begin{array}{c}\text { Age } \\
\text { (year) }\end{array}$ & $\begin{array}{c}\text { Narrow } \\
\text { body }\end{array}$ & $\begin{array}{l}\text { Wide } \\
\text { body }\end{array}$ \\
\hline 0 & 1.8 & 1.6 \\
\hline 1 & 1.8 & 1.6 \\
\hline 2 & 1.9 & 1.7 \\
\hline 3 & 1.9 & 1.7 \\
\hline 4 & 2.0 & 1.8 \\
\hline 5 & 2.1 & 1.9 \\
\hline 6 & 2.1 & 1.9 \\
\hline 7 & 2.2 & 2.0 \\
\hline 8 & 2.3 & 2.1 \\
\hline 9 & 2.3 & 2.2 \\
\hline 10 & 2.4 & 2.3 \\
\hline 11 & 2.5 & 2.3 \\
\hline 12 & 2.6 & 2.5 \\
\hline 13 & 2.7 & 2.6 \\
\hline 14 & 2.8 & 2.7 \\
\hline 15 & 2.9 & 2.8 \\
\hline 16 & 3.1 & 3.0 \\
\hline 17 & 3.2 & 3.1 \\
\hline 18 & 3.3 & 3.3 \\
\hline 19 & 3.5 & 3.5 \\
\hline 20 & 3.6 & 3.7 \\
\hline
\end{tabular}

Source: NLR (2001)

Site contamination and clearance. The value of these costs for the A320, narrow body aircraft, was randomly chosen and is $1.43 \mathrm{M} \$$. This value is considered only in cases of significant aircraft damage (major form of the accident, disaster and catastrophic).

Airline costs for delay. The costs of delay are directly related to the number of passengers on flight. The number of passengers on-board the aircraft is calculated as the product of the number of available seats and the coefficient of passengers' cabin occupancy (load factor). Compared with other cost categories, these losses are negligible.

In this paper, five different cases were defined according to values of the load factors. Specifically, it is assumed that this value ranges between $70-85 \%$, and then was simulated five different cases with different number of passengers on-board the aircraft, based on which the following data were obtained:

- Case $1: 1_{\mathrm{f}}=81 \%$ (121 passengers);

- Case $2: 1_{\mathrm{f}}=83 \%$ (124 passengers);

- Case 3: $1_{\mathrm{f}}=75 \%$ (112 passengers);

- Case $4: 1_{\mathrm{f}}=85 \%$ (128 passengers);

- Case 5: $1_{\mathrm{f}}=78 \%$ (117 passengers).

Deaths and injuries. Costs of dead and injured persons, in addition to the costs related to the aircraft damage, have the greatest impact on the final value of the direct safety costs. The total amount of these costs depends on the type of accident (Table 4), as well as on the occupancy of the passenger compartment. Apart from the number of passengers (defined in each of the five cases), the determination of these costs requires consideration of the number of crew members. It was assumed that aircraft A320 has a total of six crew members (two members of the flight crew and four cabin staff). 
An additional assumption refers to the number of persons killed and injured when the minor or moderate form of accident occurred, while for the other types of accidents that number is determined by the distribution shown in Table 4. The number of injured people is calculated as the difference between the total number of passengers and crew members on-board the aircraft and the number of casualties. These estimates are given for each of the five simulated cases.

Costs associated with fatalities as a result of an aircraft accident require definition of the value of a statistical life (VOSL), which includes an element of indemnity together with society's 'willingness to pay' to avoid catastrophic consequences. VOSL has a considerable range of possible values, depending on the state in which the accident occured (0.9-3.65 M\$) (EUROCONTROL, 2005). Value of injury accounts as $13 \%$ of VOSL.

Applying the method of random numbers, for further analysis VOSL is adopted to be $1.63 \mathrm{M} \$$. Therefore, it can be concluded that this value corresponds to the average VOSL in Europe.

Loss of staff investment. These losses occur in the event of death or serious injury of crew members that will disable them for further work. In such situations, the states are obligated to pay appropriate compensation. In addition, there may be additional costs related to training of new personnel. In this study, the costs of losing staff refer to the accidents with a high degree of damage, disaster and catastrophic, where the exact number of lost staff was randomly determined (disaster - one member; catastrophic - two members).

Loss of baggage. In order to obtain the final value of direct safety costs, the average value of the costs of loss of baggage was addopted, which is $0.21 \mathrm{M} \$$ in the case of major form of accident, disaster and catastrophic.

Airport closure. Costs of airport closure arise if the aircraft accident occures in the airport vicinity. For the purpose of this study, it was assumed that accident of the aircraft A320 did not happen near the airport, and therefore these costs are excluded from further analysis.

Third party damage. Presented study does not consider possibility of compensation to third parties, since it is assumed that the aircraft accident occured over an unpopulated area.

\subsubsection{Aircraft Indirect Safety Costs}

The most common causes of indirect safety costs (ISC) are search and rescue costs, costs of airline immediate response, costs of accident investigation, losses of investment income, increased costs of insurance and costs of loss of reputation. Since these types of costs are difficult to predict and estimate and that range of their potential values could be very large, in the present study the indirect safety costs are defined as a certain percentage value of the direct safety costs depending on the type of aircraft accident (minor: 5-15\%; moderate: 25 40\%; major: $50-70 \%$; disaster: $85-110 \%$; catastrophic: $90-140 \%)$. Subsequently, the exact percentage value of the indirect safety costs was randomly selected for each type of accident that is used in further analysis.

\section{Results of the Cost-Benefit Assessment}

Cost-benefit analysis related to possible accident of aircraft A320 is based on abovementioned direct and indirect safety costs. This research relies on several load factors of selected passenger cabin 
configuration. Detailed results for load factor $1_{\mathrm{f}}=81 \%$ (Case 1$)$ are presented in Table 6 , whilst collected results for all cases and unit safety costs are presented in Table 7 . Unit costs were calculated as total safety costs per seat and per passenger.

The provided analysis shows that the aircraft safety costs are largely a function of accident severity. Estimated cost distribution related to aircraft physical damage is as follows: minor 6.09 M\$, moderate 20.31 M\$, major 32.49 M\$, disaster $40.62 \mathrm{M} \$$, catastrophic 40.62 M\$ (Table 6).

Costs of fatalities are another important component that affects the final value of direct and indirect safety costs. Fig. 4 shows the correlation between the total amount of compensation necessary to be paid off for the casualties and injured persons in an aircraft accident and the type of accident as well as the number of passengers on-board the aircraft.
Based on specific assumptions (Table 1) for aircraft A320-200, total direct and indirect safety costs are defined for each adopted value of the load factor. The results that were obtained for a given type of aircraft by level of accident and number of passengers on-board the aircraft are shown in Fig. 5 and Fig. 6.

For example, if aircraft A320 with an average load factor of $83 \%$ (Case 2) had a major accident, the total value of the direct safety costs would be approximately $55 \mathrm{M} \$$, while the corresponding indirect safety costs (Fig. 6) would be approximately $31 \mathrm{M} \$$. In the event that the minor form of the aircraft accident occurred with the same type of aircraft and the same number of passengers on-board, these costs would be significantly lower, and would be approximately $12 \mathrm{M} \$$ (DSC), and $1 \mathrm{M} \$$ for covering indirect safety costs. Therefore, reducing total direct and indirect safety costs is in accordance with the level of aircraft damage and number of passengers on-board the aircraft in the case of an aircraft accident.

\section{Table 6}

Aircraft A320-200 Direct and Indirect Safety Costs (Case 1: $l_{f}=81 \%$ )

\begin{tabular}{|c|c|c|c|c|c|}
\hline COST CLASSIFICATION & & & ACCIDENT T & YPE & \\
\hline DIRECT SAFETY COSTS [M\$] & MINOR & \begin{tabular}{|l|} 
MODERATE \\
\end{tabular} & MAJOR & DISASTER & CATASTROPHIC \\
\hline Aircraft physical damage & 6.09 & 20.31 & 32.49 & 40.62 & 40.62 \\
\hline Possible loss of resale value & 2.03 & 2.03 & 2.03 & & \\
\hline Aircraft loss of use & 3.17 & 6.34 & 9.50 & & \\
\hline Site contamination and clearance & & & 1.43 & 1.43 & 1.43 \\
\hline Airline costs for delay & 0.003 & 0.003 & 0.003 & 0.003 & 0.003 \\
\hline Deaths and injuries & & 3.17 & 8.46 & 80.82 & 170.79 \\
\hline Loss of staff investment & & & & 0.06 & 0.12 \\
\hline Loss of baggage & & & 0.21 & 0.21 & 0.21 \\
\hline TOTAL $[\mathrm{M} \$]$ & 11.29 & 31.85 & 54.12 & 123.14 & 213.17 \\
\hline INDIRECT SAFETY COSTS [M\$] & $5-15 \%$ DSC & $25-40 \%$ DSC & $50-70 \%$ DSC & $85-110 \%$ DSC & $90-140 \%$ DSC \\
\hline Search and rescue costs & \multirow{5}{*}{1.02} & \multirow{5}{*}{10.83} & \multirow{5}{*}{30.85} & \multirow{5}{*}{121.91} & \multirow{5}{*}{266.47} \\
\hline Cost of accident investigation & & & & & \\
\hline Loss of investment income & & & & & \\
\hline Increased cost of insurance & & & & & \\
\hline Loss of reputation & & & & & \\
\hline
\end{tabular}




\section{Table 7}

A320-200 Safety Cost Estimation

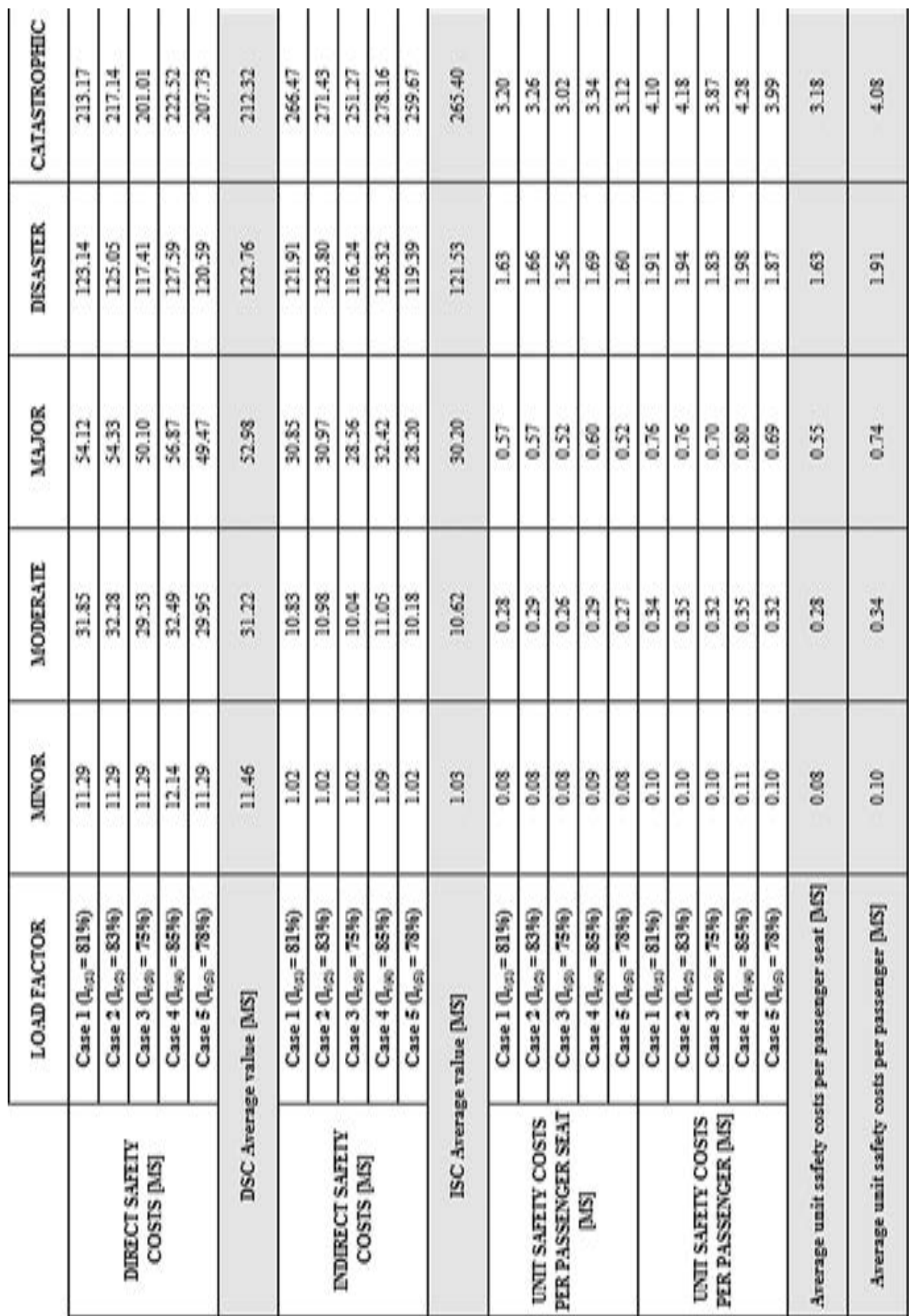


Fig. 7 shows the relation between average direct and indirect safety costs. Indirect safety costs are expressed as percentage of direct safety costs and tend to increase with increasing severity of aircraft accident. The average value of safety costs, as it can be seen from the Fig. 7, have a far greater value in the event of a catastrophic compared to the minor or moderate accident, since this types of aircraft accidents are usually accompanied by total aircraft damage, a large number of dead and injured persons, undoubtedly higher costs of accident investigation, and possibly the loss of airline reputation.

According to the previous results, unit safety costs per passenger seat logically have increasing trend depending on aircraft damage and number of casualties per accident (Fig. 8). The obtained results show that, for example, unit costs per passenger seat for aircraft A320-200 with average load factor of $81 \%$ in the case of minor accident are estimated at $0.08 \mathrm{M} \$$, whilst the costs of the disaster are more than $1.5 \mathrm{M} \$$ higher.

\section{Conclusion}

Aviation Safety Management System is continuous process crucial for maintaining and improving actual safety level during aircraft daily operations. Financial losses are lower when safety risks are detected on time, before serious accident occurs. Therefore, appropriate cost-benefit analysis presents useful tool for understanding relation between productivity and protection in aviation.

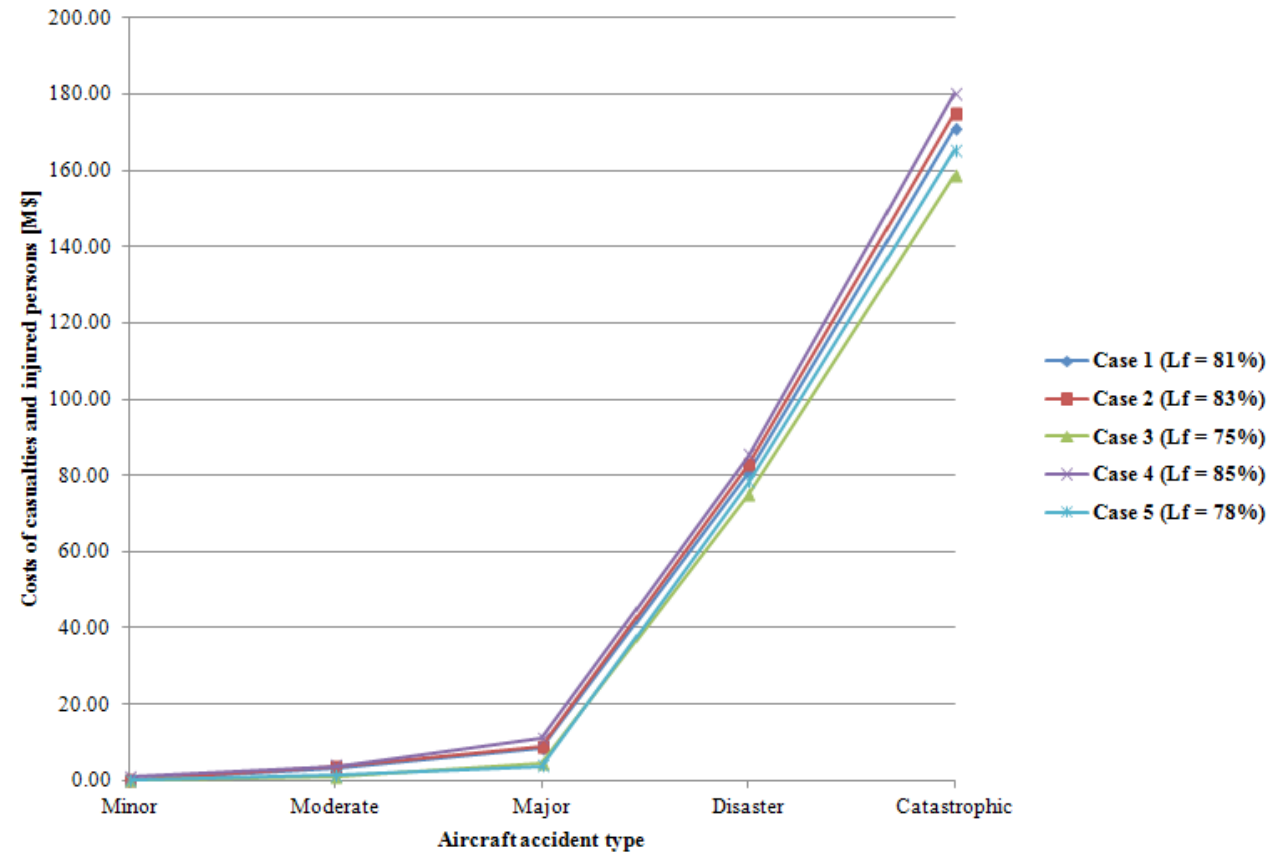

Fig. 4.

Costs of Casualties and Injured Persons 


\section{Fig. 5.}

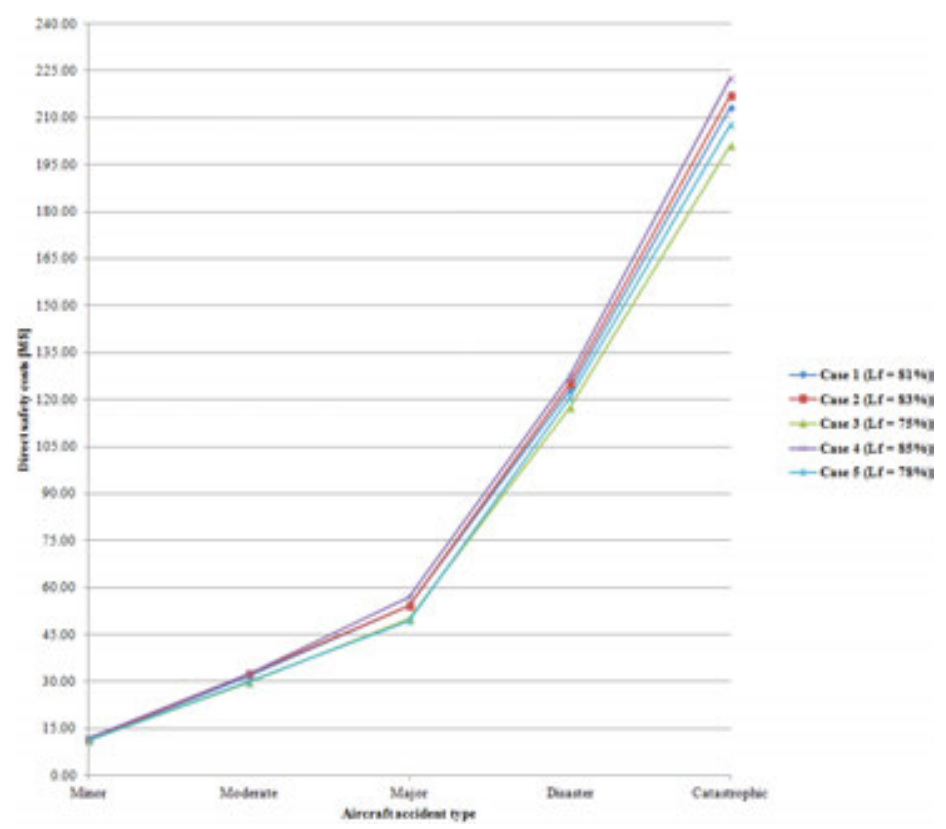

Aircraft A320-200 Direct Safety Costs

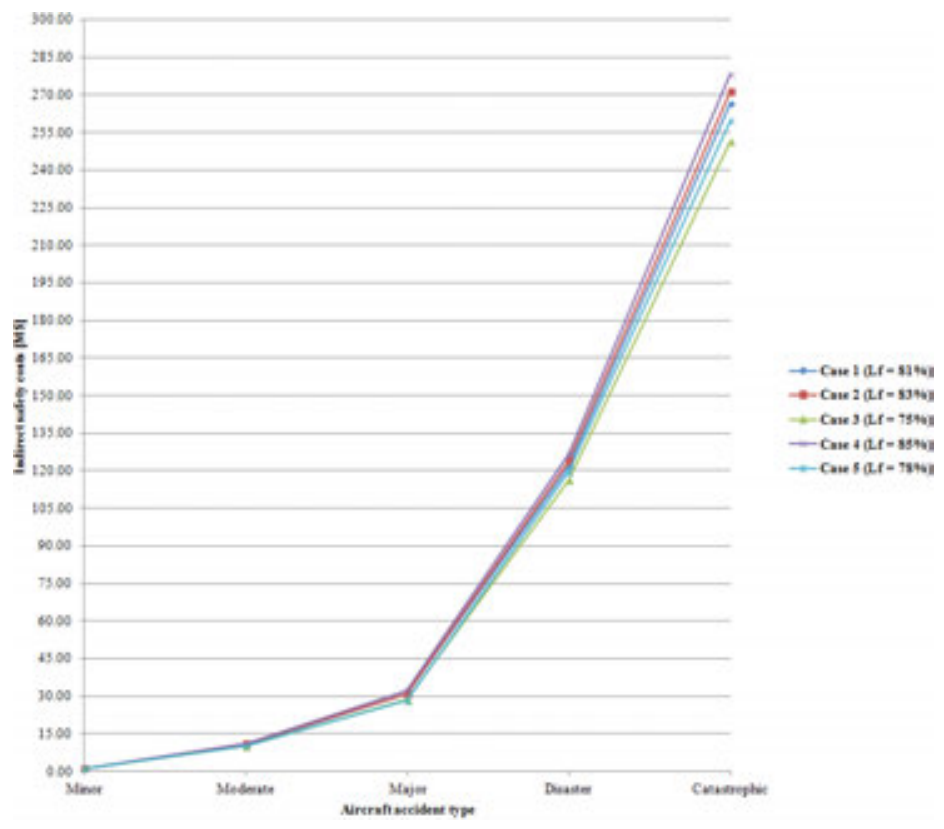

Fig. 6.

Aircraft A320-200 Indirect Safety Costs 


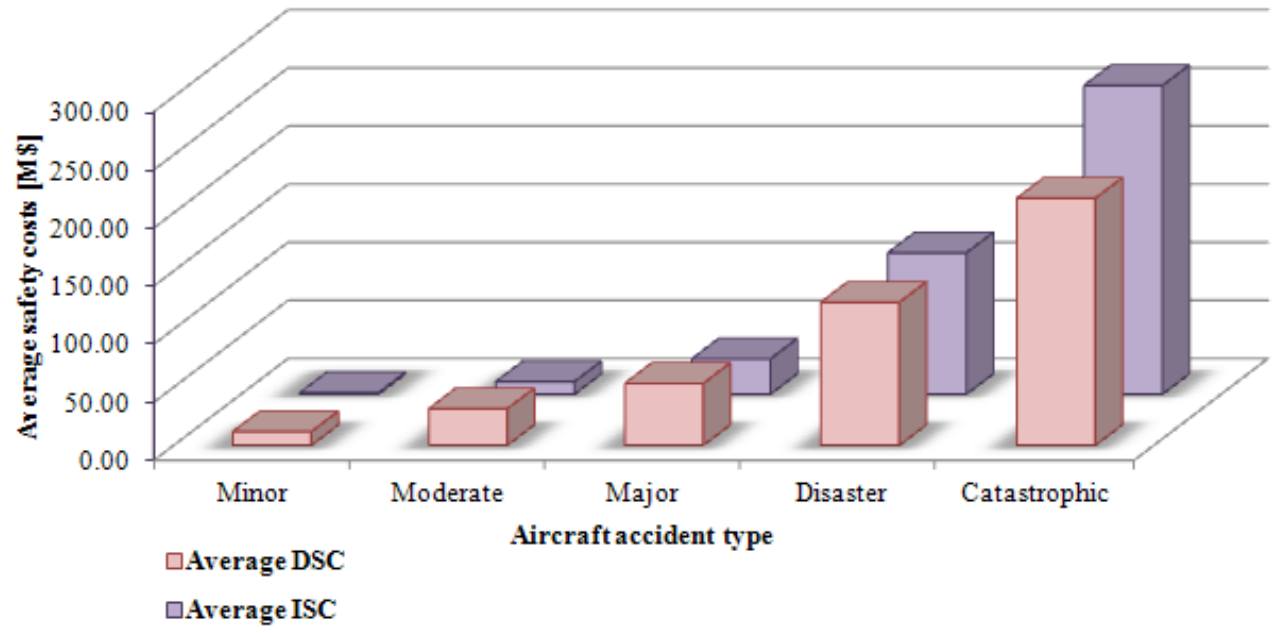

Fig. 7.

Average Direct and Indirect Safety Costs

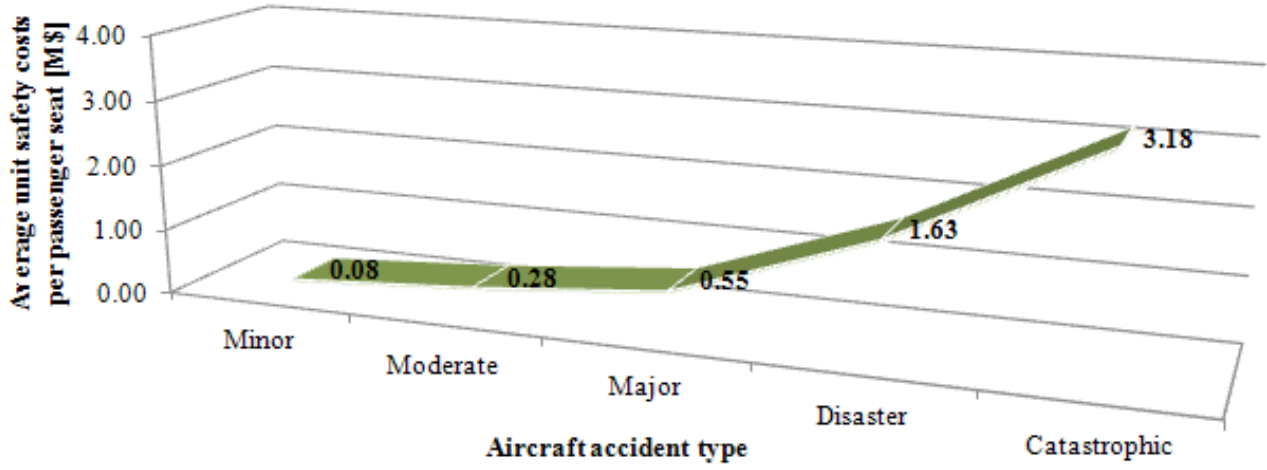

Fig. 8.

Average Unit Safety Costs per Passenger Seat 
The paper presents model for estimating direct and indirect safety related costs of aircraft accident. The model is based on accident severity and aircraft type. The provided methodology could be used for calculating total and unit safety costs of aircraft $\mathrm{A} 320$ related to passenger cabin load factor. The methodology could be applied for other aircraft types in accident analysis process. The developed analytical tool could be used for implementing SMS and measuring financial investments into safety standards in aviation industry.

\section{References}

Airbus Aircraft 2012 Average List Prices. 2012. Available from Internet: <http://www.airbus.com/presscentre/ pressreleases/press-release-detail/detail/new-airbusaircraft-list-prices-for-2012/>.

Čokorilo, O. 2008. Risk management implementation in aircraft accident cost analysis. In Proceedings of the 12th Air Transport Research Society (ATRS) World Conference, Athens. 16p.

Čokorilo, O.; Gvozdenović, S.; Mirosavljević, P. 2010 b. Metodologija za procenu troškova udesa transportnog aviona, Tehnika, 57(5): 13-18, (in Serbian).

Čokorilo, O.; Gvozdenović, S.; Vasov, Lj.; Mirosavljević, P. 2010a. Costs of unsafety in aviation, Technological and economic development of economy: Baltic Journal on Sustainability. DOI: http://dx.doi.org/10.3846/tede.2010.12, 16(2): 188-201.

Čokorilo, O.; Mirosavljević, P.; Gvozdenović, S. 2011. An approach to Safety Management System (SMS) implementation in aircraft operations, African Journal of Business Management. DOI:http://dx.doi.org/10.5897/ AJBM10.1211, 5(5): 1942-1950.

EUROCONTROL. 2005. Standard Inputs for EUROCONTROL Cost Benefit Analyses. European Organisation for the Safety of Air Navigation, 2005 Edition. $61 \mathrm{p}$.
ICAO Doc 9859. 2009. Safety Management Manual, Second Edition, Montreal. 264 p.

National Aerospace Laboratory (NLR). 2001. Aviation Safety Targets for Effective Regulation, Consolidated Final Report. 89 p.

\section{OCENA BEZBEDNOSTI VAZDUHOPLOVA PRIMENOM COST - BENEFIT ANALIZE}

\section{Ivana Čavka, Olja Čokorilo}

Sažetak: Konstantan porast obima vazdušnog saobraćaja uslovljava razvoj i implementaciju brojnih mera kojima će se omogućiti praćenje nivoa bezbednosti u radu vazduhoplovnih organizacija. Neraskidivi deo u procesu adekvatnog sprovođenja aktivnosti sistema upravljanja bezbednošću u vazdušnom saobraćaju odnosi se na analizu ekonomskih parametara za ocenu rizika od udesa vazduhoplova. Na osnovu statističkih podataka vezanih za udes razmatranog vazduhoplova A320, u radu je izvršena analiza osnovnih pokazatelja bezbednosti. Međutim, budući da udesi vazduhoplova spadaju u grupu retkih događaja, istorijski podaci ne mogu uvek biti merodavni za određivanje nivoa bezbednosti. U takvim slučajevima, potrebno je razviti matematičke modele kojima će se izračunati nivo bezbednosti. Iz tog razloga, u radu je prikazana metodologija za ocenu troškova bezbednosti vazduhoplova u slučaju udesa vazduhoplova, a koja predstavlja koristan alat u okviru sistema upravljanja bezbednošću koji ukazuje na potencijalne gubitke ukoliko nastane udes vazduhoplova, ali i na benefite koji se mogu ostvariti ulaganjima $u$ unapređenje postojećeg nivoa bezbednosti.

Ključne reči: vazduhoplov, bezbednost, costbenefit, sistem upravljanja bezbednošću. 